\title{
АНАЛИЗ БИОЦИДНЫХ ПРЕПАРАТОВ И МЕТОДОВ ИХ ПРИДАНИЯ ТКАНЯМ МЕДИЦИНСКОГО НАЗНАЧЕНИЯ
}

\section{ANALYSIS OF BIOCIDAL PREPARATIONS AND METHODS OF THEIR APPLICATION TO MEDICAL TISSUES}

\section{N. Vinogradova \\ S. Plekhanova \\ A. Plekhanov}

Summary. Currently, outpatient facilities are the largest patient care centers across the country. According to statistics provided in the State Health Development Program, outpatient facilities of the Moscow City Health Department include 483 city outpatient clinics, which are regularly visited by 6 million insured Muscovites (this is half of the capital's residents). According to the definition of the World Health Organization, nosocomial infections are any clinically expressed diseases of microbial origin that affect the patient as a result of his hospitalization or visit to a medical institution for the purpose of treatment, as well as hospital personnel by virtue of his activities, regardless of whether symptoms of this manifest or not diseases while these people are in the hospital. Nosocomial infections can be classified depending on the transmission routes: airborne (aerosol), contact-household, contact-instrumental, post-injection and other forms. Among the methods of confronting and combating nosocomial infections, methods of giving and applying antibacterial and antiseptic drugs to tissues manufactured for medical workers are distinguished.

Keywords: biocidal preparations, medical tissues, triclosan, nosocomial infections, outpatient facilities, furagin, biocidal finishes of textile materials.

$\Pi$ о статистическим данным, опубликованным бывшим главным государственным санитарным врачом Г.Г.Онищенко, удельный вес внутрибольничных инфекций (ВБИ), приходящийся на амбулаторно-поликлинические учреждения составляет 15,6\%. Этот показатель опережают только родильные дома, удельный вес ВБИ, которых составляет 46,4\%, на третьем месте находятся хирургические стационары (15,4\%).

\author{
Виноградова Наталья Алексеевна \\ Соискатель, старший преподаватель, НИУ МГСУ \\ Lisa-xumuk@yandex.ru \\ Плеханова Светлана Владиславовна \\ К.т.н., дочент, Российский государственный \\ университет им. А. Н. Косыгина \\ Плеханов Алексей Фёдорович \\ Д.т.н., професссор, Российский государственный \\ университет им. А. Н. Косыгина
}

Аннотация. В настоящее время амбулаторно-поликлинические учреждения являются крупнейшими центрами обслуживания пациентов по всей стране. Согласно статистическим данным, приведенным в Государственной программе развития здравоохранения, амбулаторно-поликлинические учреждения Департамента здравоохранения города Москвы включают 483 городские поликлиники, в которые за медицинской помощью регулярно обращаются 6 миллионов застрахованных москвичей (это половина жителей столицы). Согласно определению всемирной организации здравоохранения, внутрибольничные инфекции - любые клинически выраженные заболевания микробного происхождения, поражающие больного в результате его госпитализации или посещения лечебного учреждения с целью лечения, а также больничный персонал в силу осуществления им деятельности, независимо от того, проявляются или не проявляются симптомы этого заболевания во время нахождения данных лиц в стационаре. Внутрибольничные инфекции можно классифицировать в зависимости от путей передачи на: воздушно-капельные (аэрозольные), контактно-бытовые, контактно-инструментальные, постинъекционные и другие формы. Среди методов противостояния и борьбы с внутрибольничными инфекциями выделяют методы придания и нанесения антибактериальных и антисептических препаратов на ткани, изготовляемые для медицинских работников.

Ключевые слова: биоцидные препараты, ткани медицинского назначения, триклозан, внутрибольничные инфекции, амбулаторно-поликлинические учреждения, фурагин, биоцидные отделки текстильных материалов.

Проблема поиска путей эффективной защиты текстиля от микробиологических повреждений всегда была и остается актуальной. Это в полной мере касается и защиты хлопчатобумажного бельевого трикотажа, который непосредственно контактирует с телом человека и является чувствительным одновременно к действию целюллозоразрушительных и патогенных видов микроорганизмов. Для примера остановимся на кон- 
Таблица 1. Заправочные данные кулирной глади

\begin{tabular}{|c|c|c|c|c|c|c|c|}
\hline \multirow[t]{2}{*}{$\begin{array}{l}\text { Номер } \\
\text { образца }\end{array}$} & \multirow{2}{*}{$\begin{array}{l}\text { Волокнистый } \\
\text { состав,\% } \\
\text { и вид } \\
\text { переплетения }\end{array}$} & \multirow[t]{2}{*}{$\begin{array}{l}\text { Поверхностная } \\
\text { плотность, г/м }\end{array}$} & \multirow[t]{2}{*}{$\begin{array}{l}\text { Толщина } \\
\text { полотна } \\
\text { М, мм }\end{array}$} & \multicolumn{2}{|c|}{$\begin{array}{l}\text { Плотность - число } \\
\text { пряжи на } 10 \\
\text { см }\end{array}$} & \multirow[t]{2}{*}{$\begin{array}{l}\text { Линейная } \\
\text { плотность, } \\
\text { T, текс }\end{array}$} & \multirow[t]{2}{*}{$\begin{array}{l}\text { Вид и марка } \\
\text { красителя }\end{array}$} \\
\hline & & & & пэт. столб. & пэт. строк & & \\
\hline 1 & $\begin{array}{l}\text { Хлопок 100\% } \\
\text { (черный) } \\
\text { Кулирная гладь }\end{array}$ & 171,0 & 1,39 & 327,0 & 292,0 & 56,0 & $\begin{array}{l}\text { Кубовый } \\
\text { Akatint } \\
\text { Red } \\
\text { F5RK } \\
\text { (red 170) } \\
\text { Индия }\end{array}$ \\
\hline 2 & $\begin{array}{l}\text { Хлопок } \\
100 \% \\
\text { (красный) } \\
\text { Кулирная гладь }\end{array}$ & 150,0 & 1,13 & 316,0 & 250,0 & 52,0 & $\begin{array}{l}\text { Кубовый } \\
\text { Akatint } \\
\text { Phthalo } \\
\text { Green } 7 \\
\text { Индия }\end{array}$ \\
\hline 3 & $\begin{array}{l}\text { Хлопок, } \\
\text { 100\% } \\
\text { (зеленый) } \\
\text { Кулирная гладь }\end{array}$ & 150,0 & 1,15 & 318,0 & 251,0 & 52,0 & Кубовый Китай \\
\hline
\end{tabular}

Таблица 2. Влияние 300 часов солнечной радиации на снижение разрывной нагрузки трикотажных полотен,\%

\begin{tabular}{|c|c|c|c|c|}
\hline \multirow{2}{*}{$\begin{array}{l}\text { № } \\
\text { образца }\end{array}$} & \multirow{2}{*}{ Волокнистый состав } & \multirow{2}{*}{ Вид обработки } & \multicolumn{2}{|l|}{300 часов } \\
\hline & & & по ширине & по длине \\
\hline \multirow{4}{*}{1} & \multirow{4}{*}{ Хлопок 100\% черный } & Без обработки & 31,3 & 29,3 \\
\hline & & ETC & 7,4 & 11,9 \\
\hline & & MTC & 10,0 & 18,3 \\
\hline & & ATC & 10,5 & 19,5 \\
\hline \multirow{4}{*}{2} & \multirow{4}{*}{ Хлопок 100\% Красный } & Без обработки & 23,6 & 26,6 \\
\hline & & ETC & 15,7 & 11,2 \\
\hline & & MTC & 17,1 & 18,7 \\
\hline & & ATC & 13,5 & 15,1 \\
\hline \multirow{4}{*}{3} & \multirow{4}{*}{ Хлопок 100\% зеленый } & Без обработки & 26,6 & 35,1 \\
\hline & & ETC & 12,2 & 15,1 \\
\hline & & MTC & 13,5 & 21,4 \\
\hline & & ATC & 13,3 & 23,7 \\
\hline
\end{tabular}

кретном анализе некоторых литературных источников, посвященных этой сложной и разноплановой проблеме. Авторами работы [4, с. 63] рассмотрена безопасность биостойкости текстиля как один из основных факторов защиты текстильного сырья и готовой продукции в процессе их хранения, переработки и эксплуатации.

Биостойкость текстиля в последние годы играет ключевую роль в формировании ассортимента и свойств текстиля медицинского назначения. В работе [5, с. 33] обоснована возможность и целесообразность широкого использования для антимикробной обработки и защиты текстиля от биодеструкции различных видов отделочных препаратов, которые используют для заключительной отделки текстильных материалов и изделий. При этом основное внимание уделяется кремний-органическим, фтор-органическим и карбамольным препаратам. В работе [1] основное внимание уделяется характеристике ассортимента и свойств новых типов биоцидных и фунгицидных препаратов для защиты текстильных материалов.

Объектом исследований при решении поставленных задач служила хлопчатобумажная кулирная гладь бельевого назначения (табл. 1), полученная из хлопчатобумажной пряжи 56 текс (вариант 1) и хлопчатобумажной пряжи 52 текс (вариант 2 и 3).

Результаты исследований влияния продолжительности солнечного облучения (100, 200 и 300 час.) на из- 
Таблица 3. Результаты действия препарата на микроорганизмы в зависимости от количества стирок

\begin{tabular}{|c|c|c|c|}
\hline \multirow{2}{*}{ Количество стирок } & \multicolumn{3}{|l|}{ Зона задержки (мм) } \\
\hline & S. aureus & E. coli & K. pneumoniae \\
\hline о стирка & $3,5 \pm 0,04 \mathrm{mM}$ & О мм, незначительный рост & 0 мм, незначительный рост \\
\hline после 5 стирок & 0 мм, нет роста & 0 мм, значительный рост & 0 мм, значительный рост \\
\hline после 10 стирок & 0 мм, нет роста & 0 мм, значительный рост & 0 мм, значительный рост \\
\hline после 20 стирок & 0 мм, значительный рост & 0 мм, значительный рост & 0 мм, значительный рост \\
\hline $\begin{array}{l}\text { не обработанные образцы } \\
\text { (контрольные) }\end{array}$ & 0 мм, без сокращения роста & о мм, без сокращения роста & 0 мм, без сокращения роста \\
\hline
\end{tabular}

менение показателей светлости, насыщенности, цветового тона и общего цветового контраста, и прочности волокнистой основы, в зависимости от цвета покраски (черный, красный и зеленый) полотен до и после их антимикробной обработки препаратами ЕTC, МTC и АTC, приведены в таблицах 1-2.

В таблице 2 приведены данные, характеризующие влияние продолжительности солнечного облучения (100, 200 и 300 часов) на изменение показателей светлости, насыщенности, цветового тона и общего цветового контраста в зависимости от цвета покраски (черный, красный, зеленый) полотен до и после их антимикробной обработки препаратами ЕTC, МТС и АТС. При этом установлено: среди трех цветовых характеристик покраски трикотажных полотен до и после обработки препаратами ETC, MTC и ATC под действием длительного солнечного облучения (300 часов) наиболее существенные изменения происходили в показателе цветового тона; обработка препаратами ЕТС, МТС и АТС исследуемых полотен, как правило, приводит к существенному повышению светостойкости покрасок, при этом лучший эффект достигается после обработки полотен черного и зеленого цветов.

Таким образом, выбранные нами тиосульфонатные препараты ETC, MTC и ATC пригодны не только для эффективной защиты от микробиологической деструкции, но и от длительного действия светопогоды хлопчатобумажных трикотажных полотен летнего ассортимента.

Как известно [7, с. 323; 9, с. 7; 12], в износе хлопкового трикотажа летнего ассортимента действие света как и целюллозоразрушающих микроорганизмов, играет ключевую роль. А потому важно, чтобы способы обработки хлопчатого бельевого трикотажа одновременно предоставляли высокую светостойкость и биостойкость.

Как видно из анализа таблицы 2, выбранные для обработки хлопкового трикотажа препараты ЕTC, МTC и АTC существенно тормозят процесс атмосферной деструк- ции исследуемых трикотажных полотен. Если после 300 часов облучения разрывные нагрузки полотен по ширине и длине до обработки биоцидным препаратом ЕTС снижается соответственно на 31,3 и 29,3\%, то после обработки ЕТС, это снижение составляет 7,4\% и 11,9\%. Подобная закономерность наблюдается и после обработки препаратами МТС и АТС полотен вариантов 1,2 и 3.

Выбранные нами тиосульфонатные препараты существенно тормозят обесцвечивания исследуемых трикотажных полотен вар. 1,2 и 3 в процессе их солнечной радиации. При этом лучший светостабилизирующий эффект, как правило, достигается после обработки полотен препаратами ЕTC.

Можно сделать вывод, что выбранные нами препараты для антимикробной обработки обеспечивают надлежащую светостойкость покраски и волокнистой основы исследуемых тканей. Поэтому при формировании заданной светостойкости, текстильных одежных материалов медицинской отрасли, следует учитывать не только их устойчивость к действию различных групп и видов микроорганизмов, но и состав волокон, вид красителя и биоцидного отделочного препарата в процессе их микробиологического и атмосферного старения.

Изучена возможность и обоснована целесообразность использования в отечественном текстильном производстве тиосульфонатных отделочных препаратов ETC, MTC и ATC для антимикробной обработки хлопчатобумажных бельевых трикотажных полотен летнего ассортимента с целью их эффективной защиты от биодеструкции патогенными микроорганизмами.

Установлено, что в процессе антимикробной обработки исследуемых хлопчатобумажных трикотажных полотен препаратами ETC, MTC и ATC не наблюдается заметных изменений на их механические (разрывная нагрузка) свойства, что может ухудшить износостойкость и гигиеничность названных полотен в процессе эксплуатации изделий из них. 
Не выявлено отрицательного влияния обработки препаратами ETC, MTC и ATC на изменение цветовых характеристик (светлости, насыщенности, цветового тона и общего цветового контраста) и по светостойкости окрасок исследуемых трикотажных полотен кубовыми красителями.

Установлено, что антимикробные препараты ЕTC, MTC и ATC способны эффективно защищать хлопчатобумажные бельевые трикотажные полотна летнего ассортимента от длительного воздействия солнечной радиации [3, с. 72].

Основным преимуществом тиосульфонатных отделочных препаратов является то, что их использование гарантирует одновременное достижение на трикотажных хлопчатобумажных бельевых и одежных полотнах высокой атмосферостойкости без ухудшения их механических свойств.

Действующее вещество было нанесено уже на готовые ткани, приобретенные в магазине.

Испытания проводились в соответствии с требованиями стандарта EN ISO 20645:2004. Результаты полученных данных приведены в таблице 3.
Результаты таблицы 3 показывают, что образец способен противостоять золотистому стафилококку вплоть до 20 стирок. На нулевой стирке образец проявляет антибактериальные свойства, а после пятой стирки он не допускает размножение бактерий, что тоже является хорошим показателем. Что касается кишечной палочки и палочки Фридлендера, то здесь дела обстоят хуже. Образец способен бороться с бактериями до 5 стирок включительно.

Самой простой технологией получения тканей с антибактериальными свойствами является нанесение раствора на готовые ткани. Это может быть как орошение поверхности материала, либо его помещение в раствор на определенное время.

В настоящее время разрабатывается и уже используется большое количество технологий нанесения биоцидных препаратов на поверхность или в структуру текстильного материала. Из приведенного материала можно сделать вывод о том, что наиболее резистентен в борьбе с вредоносными микроорганизмами такой текстильный материал, который сохраняет свои антибактериальные свойства на протяжении нескольких стирок. Разработка такого материала имеет первоочередную ценность и интерес.

\section{ЛИТЕРАТУРА}

1. Астафуров В. Н. Руководство по уходу за больным и общей хирургии: электрон. учеб. [Электронный ресурс] / В. Н. Астафуров. Режим доступа: httр://www. surgerymanual.front.ru.

2. Барбинов В.В.Исследование антимикробных свойств биоцидного препарата «Санитайзед-Т 99-19» в профилактике внутрибольничных инфекций/ В. В. Барбинов, А. М. Иванов, Р. А. Раводин, О. В. Попова // Вестник Российской Военно-медицинской академии. 2009. № 1 (25). прилож. ч. 1.

3. Баранова 0. Н. Разработка метода придания антисептических свойств целлюлозным текстильным полотнам бельевого ассортимента и оценка их качества: дис. ... канд. техн. наук: 05.19.01/ Баранова Ольга Николаевна. М. 2012.

4. Виноградова Н. А. Кинетика изнашивания тканей специального назначения // Известия высших учебных заведений. Технология текстильной промышленности. 2019. № 3.

5. Виноградова Н.А., Плеханова С. В. Выбор определяющих показателей качества тканей медицинского назначения // Известия высших учебных заведений. Технология текстильной промышленности. 2016. № 1.

6. Донецкая Э.Г.-А. Клиническая микробиология: руководство для специалистов клинической лабораторной диагностики / Э.Г.-А. Донецкая. М.: ГЭОТАР-Медиа. 2011.

7. Зефиров Н. С. Химическая энциклопедия: в 5 т. / Н. С. Зефиров. М.: Советская энциклопедия. 1995. Т. 4.

8. Методические указания по лабораторной оценке антимикробной активности текстильных материалов, содержащих антимикробные препараты. М. ВНИИДиС. 1984.

9. Олтаржевская Н. Д. Новые способы получения лечебных текстильных материалов. / Н. Д. Олтаржевская //Трикотажная и текстильно-галантерейная промышленность. М.: ЦНИИТЭ Илегпром. 1992. № 1.

10. Онищенко Г.Г. Письмо Роспотребнадзора № 01/5272-12-32 от 11.05 .2012 «0 мерах по недопущению возникновения вспышек внутрибольничных инфекций». М. 2012.

11. Разуваев А. В. Биоцидная защита текстильных материалов для профессиональной одежды/ А. В. Разуваев// Технический текстиль. 2009. № 19.

12. Уварова 0. Бактериостатические ткани. / 0. Уварова // Российский деловой журнал Би К. 2006. № 6.

13. Хазанов Г. И. Зависимость антимикробной активности текстильных материалов от характера распределения препаратов на волокне / Г. И. Хазанов // Текстильная промышленность. 2000. № 1.

14. AATCC Test Method 100-2004 Antibacterial finishes on textile materials: Assessment of. AATCC Technical Manual, American Association of Textile Chemists and Colorists. Research Triangle Park. NC. 2005. 
15. Cen L. Antibacterial activity of cloth functionalized with Nalkylated poly (4-vinylpyridine)/ Cen L., Neoh K. G., Kang E. T. // Wiley Periodicals, Inc. Journal of Biomedial Materials Research. 2004. № 71(A).

16. Gouda M. Enhancing flame-resistance and antibacterial properties of cotton fabric/ M. Gouda// Journal of Industrial Textiles. 2006. 36(2).

17. Gribust I. (2018). Regulation of the state of plantings in the anthropogenically transformed territories: the principle of dendrological diversity. World Ecology Journal. 8(2). https://doi.org/https://doi.org/10.25726/NM.2018.2.2.002

18. Kimiran Erdem A. The Evaluation of Antibacterial Activity of Fabrics Impregnated with Dimethyltetradecyl (3-(Trimethoxysilyl) Propyl) Ammonium Chloride/ Kimiran Erdem, A., Sanli Yurudu, N.0. // IUFS Journal of Biology. 2008. № 67 (2).

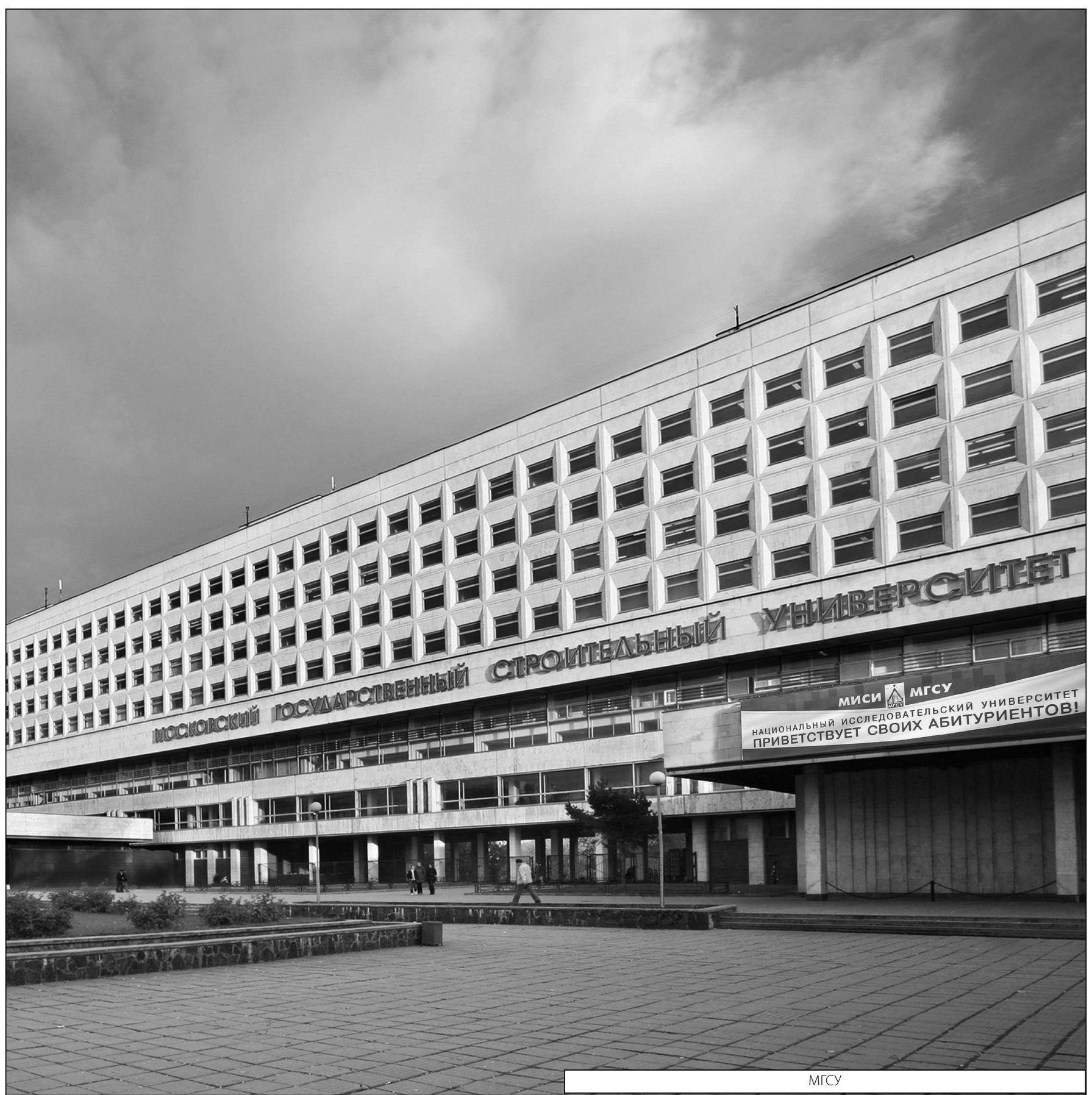

